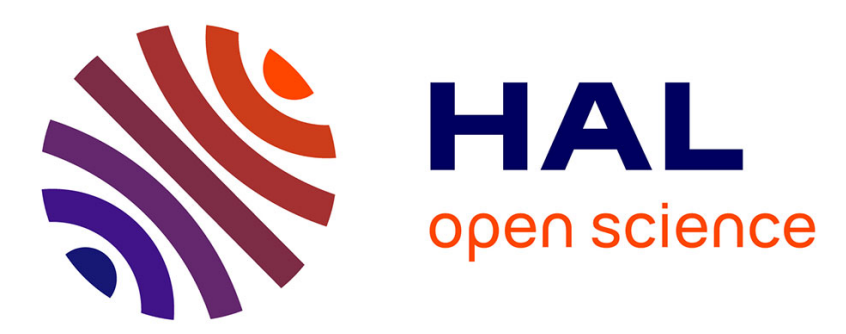

\title{
Rumen contents of charolais cows during the grazing period
}

\author{
Jacques Agabriel, M Petit, Jm Giraud
}

\section{To cite this version:}

Jacques Agabriel, M Petit, Jm Giraud. Rumen contents of charolais cows during the grazing period. Annales de zootechnie, 1993, 42 (2), pp.162-162. hal-00888901

\section{HAL Id: hal-00888901 https://hal.science/hal-00888901}

Submitted on 1 Jan 1993

HAL is a multi-disciplinary open access archive for the deposit and dissemination of scientific research documents, whether they are published or not. The documents may come from teaching and research institutions in France or abroad, or from public or private research centers.
L'archive ouverte pluridisciplinaire HAL, est destinée au dépôt et à la diffusion de documents scientifiques de niveau recherche, publiés ou non, émanant des établissements d'enseignement et de recherche français ou étrangers, des laboratoires publics ou privés. 


\title{
Rumen contents of charolais cows during the grazing period
}

\author{
J Agabriel 1, M Petit 1, JM Giraud 2 \\ 1 INRA, laboratoire Lactation et Élevage des ruminants, 63122 Theix; \\ 2 INRA, domaine des Razats, 63820 Laqueuille, France
}

Six to 9 Charolais rumen-fistulated cows were used during 3 successive years to measure the weight of rumen content by total emptying: 1) before turnout to grass, on limited hay diets (10 $\mathrm{kg}), 5 \mathrm{~h}$ after morning feeding (V1); 2 ) 2 or $3 \mathrm{wk}$ after turnout, when cows were grazing the first grass growth (V2); 3) 2 months after turnout (August) at the third cycle of grass growth, in a rotational system (V3); 4) in autumn on aftermaths (6-7 wk old) after a late cut for hay (V4). These measurements were carried out during the third $\mathrm{d}$ after a paddock change between 2 and $4 \mathrm{pm}$. Samples were taken approximately every 10 handfuls to determine the DM content of the rumen digesta.

After turnout, between $V_{1}$ and $V_{2}$, rumen content rapidly dropped by $28 \mathrm{~kg}$, then increased steadily from $V_{2}(76 \mathrm{~kg})$ to $V 3(82$ $\mathrm{kg})$ and $\mathrm{V} 4(92 \mathrm{~kg})(\rho<0.05$ between $\mathrm{V} 2$ and V4). This was mainly the result of the increase in the dry content of the rumen ( 7.9 to $10.4 \mathrm{~kg} p<0.05$ ) while the DM percentage did not change significantly and remained around $10.5 \%$.

This increase in the weight of rumen content may result from: 1) a reduction in grass digestibility (not measured), although the grass available was always leafy; 2) the reduction in time elapsed between the large meal in the morning and rumen emptying (Beaumont, 1989): in september the large meal was taken at 7 am vs 5 am in June.

Live weight did not change between $V 1$ and V2 $(610 \mathrm{~kg})$, but increased from V2 to
V3 $(650 \mathrm{~kg})$ then V4 $(691 \mathrm{~kg})$. On the hypothesis of a constant proportion of rumen content in total gut content $(80 \%$, Béranger and Robelin, 1978), the empty body mass recovered during these 3 periods reached 31,32 and $31 \mathrm{~kg}$. The daily gain reached $1.8 \mathrm{~kg}$ during the 2 first wk at grass then decreased to $0.55 \mathrm{~kg}$ in autumn.

In cows at grass, rumen contents accounted for $15 \%(\mathrm{~V} 2, \mathrm{~V} 3$ ) then $25 \%$ (V3, $\mathrm{V} 4)$ of total liveweight gain. This should be taken into account to calculate the body reserves recovered.

Béranger C, Robelin J (1978) Ann Zootech 27, 639-645

Beaumont $R$ (1989) Thèse Doct Ing INA-PG Paris, $159 \mathrm{pp}$

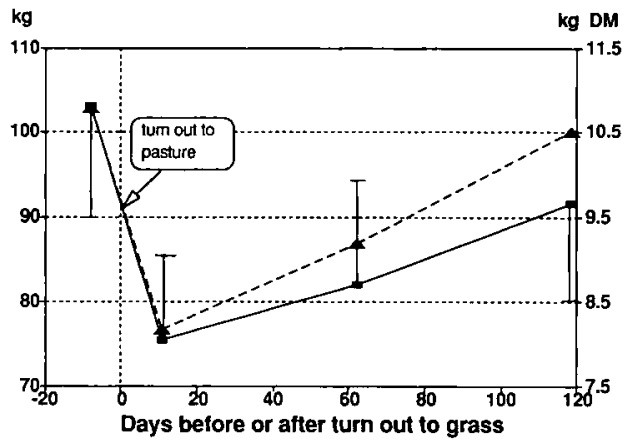

Fig 1. Evolution in weight of wet $(\longrightarrow$ ) and dry $(-\mathbf{A}-)$ rumen content. 